\title{
Socio-ecological Status and Antibacterial Activity of Paris polyphylla from Panchase Area of Kaski District
}

\author{
Meena S. Chhetri, Yajna P. Timilsina, Hari P. Tripathee and Krishna P. Devkota \\ Institute of Forestry, Tribhuvan University \\ Pokhara Campus, P. O. Box: 43, Pokhara, Nepal \\ e-mail:devkotakpd@yahoo.com
}

\begin{abstract}
The research conducted in Panchase area of Kaski district aimed to assess the ecological and social status of Paris polyphylla with its antibacterial activity and ethno-medicinal uses of available plant species. P. polyphylla shows relative density, frequency and coverage of 5.26/ha, 6.29\% and 3.05\%, respectively. Similarly, the importance value index of this plant was found to be 14.6. Rhizomes of this plant in the study site are mainly applied to wounds for rapid healing and antidote to the bite for poisonous insects and snakebite, fever, headache and stomach problem of both human and domestic animals. Different extracts of aerial parts of the plant are active against Bacillus subtilis, Staphylococcus aureus, Pseudomonas aureginosa, Escherchia coli and Salmonella flexinerai whereas, rhizome extract was active only against $S$. aureus. Petroleum ether extract from the rhizomes of $P$. polyphylla was most effective against $S$. aereus with minimal inhibitory concentration value of $62.5 \mathrm{mg} / \mathrm{ml}$.
\end{abstract}

Key words: ecological, importance value, minimum inhibitory concentration, paris polyphylla, zone of inhibition, index and social status

\section{Introduction}

Panchase forest area is situated at the nexus of three districts, Kaski, Parbat and Syanja in the Western Region of Nepal. It covers an approximate area of 10-12 square kilometer situated in the altitude range of 1400 - 2517 $\mathrm{m}$. It is one of the largest source of different NTFPs. The forest is mainly divided into two zones: sub-tropical zone which is dominated by Schima wallichii- Castanopsis indica- Daphniphyllum himalense and temperate zone that is dominated by Quercus semicarpifolia-Quercus lamellose-Rhododendron arboretum. The local people consider the Panchase forest and the mountain peak (2509 $\mathrm{m}$ ) as a sacred landscape and it has special religious significance for both Hindu and Buddhists. Major ethnic groups are Brahmin, Chhetri, Gurung, Bishwokarma, Nepali, Pariyar, Magar and Thakali. The Panchase Forest is major source of water for agricultural and domestic use in the surrounding communities, as well as the primary source area for a number of local watersheds including Phewa Lake Watershed. Furthermore this forest PFE is rich in biodiversity, home to a variety of endangered wildlife such as black bear, leopard, etc. and rare and endemic plants including orchids and rhododendron. It also represents a critical linkage between Chitwan-Annapurna range and an important component of Greater Himalayan Landscape containing diverse medicinal plants.

Medicinal plants are the local heritage with global importance. The world is endowed with a rich wealth of medicinal plants. Herbs have always been the principal form of medicine and they are becoming popular throughout the world, as people strive to stay healthy in the face of chronic stress and pollution, and to treat illness with medicines that work in concert with the body's own defenses (Manandhar 1993). Medicinal plants also play an important role in the lives of rural people particularly in remote parts of developing countries with few health facilities (Prajapati \& Purohit 2003). The plants are the most valuable resources of Nepal, which provide wide range 
of useful products: food, medicine, timber, fodder, fuel wood, fiber, condiments, etc. Among different plant resources, medicinal and aromatic plants (MAPs) have been considered as one of the most precious and important source of medicine for the local healers in the villages, as well as the basic raw materials for Ayurvedic, Tibetan, Homeopathethic and Allopathic medicines. Medicinal plants have curative properties due to the presence of various complex chemical substances of different composition which are found as secondary plant metabolites in one or more parts of these plants (Prajapati \& Purohit 2003).

P. polyphylla Smith (Local name: Satuwa) is broadleaved perennial plant that has a preference to woodlands, forests, bamboo forests, thickets, grassy or rocky slopes and streamside. It is distributed in Himalayan region from Kashmir to Bhutan and Western region in China. It grows naturally in subtropical and alpine zones. It can grow in full shade (deep woodland) or semi-shade (light woodland) moist habitat mostly on the exposed north facing slopes (Dutta 2007). In Nepal, P. polyphylla is distributed abundantly in Eastern, Mid and Western regions between 2000-3000 m elevation range with associated Rhododendron species, Daphniphyllum himalense, etc. The average market price of $P$. polyphylla is Rs. 260-350 per kg. The rhizomes have high demands in both national and international markets for its valuable rootstock to treat variety of ailments (Bhattarai \& Ghimere 2006).

\section{Methodology}

Study area selection

Panchase forest is considered as a one of the large sources of non-timber forest products including medicinal plants. Altogether 335 species of flowering plants including 107 species of orchids together with some valuable medicinal and aromatic plants such as $P$. polyphylla, Swertia chiraita, Taxus baccata, Asparagus racemosus, Rubia cordifolia, etc. were reported from this forest area (MDO 2005) stimulated us to conduct a research on the selected site.

\section{Data collection}

Social Data Collection (Exploration of ethnomedical knowledge)

Participatory rural appraisal tools (structured questionnaire, household survey, key informant interview) were used to explore ethnomedicinal knowledge of the rural people of Bhadaure Tamagi VDC of Panchase area. At least $10 \%$ respondents were selected for the structured questionnaire household survey to understand their knowledge regarding ethnomedicinal uses of $P$. polyphylla. Key informants interview (comprising of the local collectors, middlemen, women and Dhami) were conducted to collect information on distribution status and utilization of $P$. polyphylla.

\section{Biophysical data collection}

Biophysical data were collected by following four methods:

- Preliminary survey: First of all, preliminary survey of the $P$. polyphylla habitat was done before starting the study to identify the appropriateness and adequacy of data and to ensure better results as well as to observe the habitat characteristics of the targeted species.

- Participatory Resource Mapping (PRM): PRM was drawn to identify the potential areas of $P$. polyphylla inside forest area.

- Direct Field Observation: It was done in and around the field site for the identification of MAPs species including $P$. polyphylla. It helped in the verification of the accuracy of participatory mapping. The species composition, their number and condition were observed in the forest during field observation.

- $\quad$ Area Delineation: After above study, the best $P$. polyphylla habitat of 58 ha was identified in Panchase protected forest possessing northern aspect and was surveyed by using GPS. Then, inventory was done within that total surveyed area according to plotless survey method (Rabindranath Premnath 1997).

\section{Data analysis}

Data collected during field visit and sampling were thoroughly analyzed both quantitatively and qualitatively using appropriate statistical tools depending upon nature of data. Both quantitative and qualitative data were analyzed as described by Dingle et al.1953, WHO 1991, Salie et al. 1996 and Rabindranath and Premnath 1997.

\section{Laboratory test \\ Plant processing and extraction}

The healthy plants of $P$. polyphylla were collected from the study site. The plants were processed according to the method of Salie et al. (1996) and 
separated into aerial and underground parts. Each separated part was chopped into small pieces and shade dried. The dried plants were ground and extracted using different solvents such as petroleum ether, chloroform, methanol and water which was then concentrated to yield crude extract of respective solvents. Five hundred miligrams of each extract was transferred into a clean, dry and sterile test tube and 1 $\mathrm{ml}$ of ethanol was added to each tube to make $500 \mathrm{mg} /$ ml dilutions which was used for the determination of the zone of inhibition (ZOI) of tested bacteria. Lower concentrations (250, 125, 62.5, 31.25 and $15.625 \mathrm{mg} /$ $\mathrm{ml}$ ) were also used to determine minimum inhibitory concentration (MIC).

\section{Antibacterial activity test}

Preparation of stock culture of bacteria

Five strains of bacteria such as Bacillus subtilis, Staphylococcus aureus, Pseudomonas aureginosa, Escherichia coli and Salmonella flexinarae were used for the screening process. All of the tested bacteria were received from western regional hospitals (WRH) and Pokhara cultured collections.

Agar well diffusion technique (Cup plate technique) In this technique, small cups (wells) were made by a 4 mm cork borer in petri-plates containing Muller Hinton Agar medium and inoculated test organism (Devkota \& Dutta 2001). The diluted extract (test solution) was added to the wells. Which were then placed in an incubator at $37^{\circ} \mathrm{C}$ for $18-24$ hours and the zone of inhibition was measured. This method was successfully used by Pepeljnjak et al. (1999) and Devkota et al. 2000. The antibiotics, ciprofloxacin and norfloxacin were used as standard drugs during the assay.

\section{Two fold serial dilution technique}

This is a technique used to determine MIC of bioactive compounds. This technique was recommended by WHO (1991) and used successively by Devkota et al. (2000) et al. and Devkota \& Dutta (2001).

\section{Results and Discussion \\ Ethno-medicinal knowledge of $\boldsymbol{P}$. polyphylla and associated species}

The ethno-medicinal uses of $P$. polyphylla and its associated species that are found in Panchase forest area of Kaski district are presented in Table 1. The findings indicated that together with $P$. polyphylla, there are several other medicinal plant species in the study site that are being used by local people to treat different diseases and also in their seasonal cookery. People have full faith with those medicinal plants and majority of the respondents wanted to continue this practice and sustain it by conserving those species in their natural habitat.

Table 1. List of medicinal plants with their ethno-medicinal uses found in Panchase forest

\begin{tabular}{|c|c|c|c|c|}
\hline $\mathrm{SN}$. & $\begin{array}{l}\text { Botanical tame } \\
\text { (Family) }\end{array}$ & $\begin{array}{l}\text { Local } \\
\text { Name }\end{array}$ & Parts used & Ethromedicinal uses \\
\hline 1. & $\begin{array}{l}\text { P. polyphylla } \\
\text { (Liliaceae) }\end{array}$ & Satuwa & Rhizomes & $\begin{array}{l}\text { - Root paste is applied to wounds for tapid healing and } \\
\text { artidote to the bite for pois onous ins ects and strakebite. } \\
\text { - Rhizome powder is used for fever, headache and stomach } \\
\text { problem of both luman and domestic arimals. } \\
\text { - Chewing a piece of thizome is believed to alle viate } \\
\text { drunkardness and throat problem. }\end{array}$ \\
\hline 2. & $\begin{array}{l}\text { Swertia chiraita } \\
\text { (Gentianaceae) }\end{array}$ & Chiraito & Whole plant & $\begin{array}{l}\text { Juice of platt boilet in water is used to get telief from } \\
\text { fever, body ache, cough, stomach pairing, gastric } \\
\text { problem, malaria, typhoid, highblood pressute, } \\
\text { diabetes and joint problem. }\end{array}$ \\
\hline 3. & $\begin{array}{l}\text { Asparagus } \\
\text { racemosus } \\
\text { (Liliaceae) }\end{array}$ & Kurilo & $\begin{array}{l}\text { Iender shoots, } \\
\text { Roots }\end{array}$ & $\begin{array}{l}\text { Root paste is talken to treat fe ver and as a tonic to } \\
\text { lactatitg women and lives tock. I ender shoots are } \\
\text { cooked as regetable. }\end{array}$ \\
\hline
\end{tabular}


Nepal Journal of Science and Technology Vol. 13, No. 2 (2012) 167-174

\begin{tabular}{|c|c|c|c|c|}
\hline 4. & $\begin{array}{l}\text { Berberis } \\
\text { aristata } \\
\text { (Berberidaoae) }\end{array}$ & Chutro & Fruit & Fruits are edible and used for rnaking alcohol. \\
\hline 5 . & $\begin{array}{l}\text { Rubus elliwoticus } \\
\text { (Rosaceae) }\end{array}$ & Ainselu & $\begin{array}{l}\text { Roots, Fruit, } \\
\text { Tender shoot }\end{array}$ & $\begin{array}{l}\text { Ripe fuits are eaten. Tender shoots are used to treat } \\
\text { fever. Root juice is used to treat typhoid and incligestion }\end{array}$ \\
\hline 6. & $\begin{array}{l}\text { Bergina ciliate } \\
\text { (Saxifragaceae) }\end{array}$ & $\begin{array}{l}\text { Pakhart } \\
\text { ved }\end{array}$ & Rhizorres & $\begin{array}{l}\text { Juice from rhizome is useful in joint problem. } \\
\text { Rhizore is also used as an antidote. }\end{array}$ \\
\hline 7 . & $\begin{array}{l}\text { Lindera neesiona } \\
\text { (Lauraeae) }\end{array}$ & Sil tirrour & Seed & $\begin{array}{l}\text { Seeds are used in treatirg storrach paining and } \\
\text { diarnhea. }\end{array}$ \\
\hline 8. & $\begin{array}{l}\text { Acorus calorns } \\
\text { (Araceae) }\end{array}$ & Bojko & Rhizorres & $\begin{array}{l}\text { Rhizorres are used to treat cough, oold, throat } \\
\text { infection, dianhea. }\end{array}$ \\
\hline 9. & $\begin{array}{l}\text { Girardiana } \\
\text { diversifolia } \\
\text { (Urticaeae) }\end{array}$ & Allo & $\begin{array}{l}\text { Roots, Tender } \\
\text { Parts }\end{array}$ & $\begin{array}{l}\text { Terder parts are boiled and eaten as vegetables. Root } \\
\text { juice is used for cooling purpose ard fever. }\end{array}$ \\
\hline 10. & $\begin{array}{l}\text { Gssampelos } \\
\text { pareira } \\
\text { (Merisperracea) }\end{array}$ & $\begin{array}{l}\text { Batulpate } \\
\text { lahara }\end{array}$ & Whole plant & $\begin{array}{l}\text { Plant peste is given to livestock to stopbleeding and } \\
\text { counteract the loss of blood }\end{array}$ \\
\hline 11. & $\begin{array}{l}\text { Ampelocissus } \\
\text { divarcata } \\
\text { (Vitaceae) }\end{array}$ & Pureni & Whole plant & Plant juice is used to treat inflarmation of eye. \\
\hline 12. & $\begin{array}{l}\text { Rhrsjaranica } \\
\text { (Aracardiaceae) }\end{array}$ & Bhakimlo & Seeds & Power of seed is used to treat stomach pairing. \\
\hline 13. & $\begin{array}{l}\text { Geilarthes anceps } \\
\text { (Pteridaceae) }\end{array}$ & Rari jhar & Whole plant & $\begin{array}{l}\text { Plant poste is used in wound after operation } \\
\text { as an analgesic. }\end{array}$ \\
\hline 14. & $\begin{array}{l}\text { Uhtica dioca } \\
\text { (Urticaceae) }\end{array}$ & Simu & $\begin{array}{l}\text { Roots, tender } \\
\text { shoots }\end{array}$ & $\begin{array}{l}\text { Terder shoots are used as vegetable. Root juice is } \\
\text { used for cooling purpose. }\end{array}$ \\
\hline 15 . & $\begin{array}{l}\text { Aliumblanswm } \\
\text { (Armarzlidaceae) }\end{array}$ & Ban lasun & Rhiworne & Rhizorre is used to treat uric acid and storach problem \\
\hline 16. & $\begin{array}{l}\text { Daphre bholua } \\
\text { (Thyrrelaceae) }\end{array}$ & Lokta & Bark, Roots & $\begin{array}{l}\text { Roots are used for parasites. Bark of the stem is used } \\
\text { for making ropes. }\end{array}$ \\
\hline 17. & $\begin{array}{l}\text { Adiontum caudatum } \\
\text { (Adiantaceae) }\end{array}$ & Fem & Whole plant & Plant peste is used to control bleedirg. \\
\hline 18. & $\begin{array}{l}\text { Tinospora sinensis } \\
\text { (Merisperraceae) }\end{array}$ & Gurjo & Whole plant & $\begin{array}{l}\text { Plant is used for uninaryproblem. Root juice is used } \\
\text { to treat dianhea and dyeentery. }\end{array}$ \\
\hline 19. & $\begin{array}{l}\text { Combretum } \\
\text { Roxburghii } \\
\text { (Corbretaea) }\end{array}$ & Thakailo & Root & Root juice is used to treat fever and cooling purpose. \\
\hline 20. & $\begin{array}{l}\text { Centella asiatica } \\
\text { (Urbelliferae) }\end{array}$ & Ghotapre & Leaves & $\begin{array}{l}\text { Leaves are used as a vegetable. Plant is used for } \\
\text { treatment of skin diseases and for cooling purpose. }\end{array}$ \\
\hline 21. & $\begin{array}{l}\text { Costus speciosus } \\
\text { (Zirgiberaceae) }\end{array}$ & Betlauni & Roots & Root paste is used for throat problem. \\
\hline 22. & $\begin{array}{l}\text { Gssampelis } \\
\text { Pareira } \\
\text { (Merisperraceae) }\end{array}$ & $\begin{array}{l}\text { Gujar- } \\
\text { garo }\end{array}$ & Whole plant & $\begin{array}{l}\text { Roots are used in cough, diarrea, srake-bite, etc. } \\
\text { Leaves are exterrallyapplied for itch. }\end{array}$ \\
\hline
\end{tabular}


Meena S. Chhetri et al./Socio-ecological Status .....

\begin{tabular}{|c|c|c|c|}
\hline 23. & $\begin{array}{l}\text { Artenisia vilgaris } \\
\text { (Cormocitae) }\end{array}$ & Titepati & Leaves \\
\hline 24. & $\begin{array}{l}\text { Imperdata cylindrical } \\
\text { (Graminex) }\end{array}$ & Sin & Roots \\
\hline 25. & $\begin{array}{l}\text { Mahonia napaulensis } \\
\text { (Berberidaoeae) }\end{array}$ & $\begin{array}{l}\text { Jarmanemt } \\
\text { andre }\end{array}$ & Bark \\
\hline 26. & $\begin{array}{l}\text { Polypodiodes } \\
\text { amoena } \\
\text { (Folypodiaceae) }\end{array}$ & Bishplej & Rhizome \\
\hline 27. & $\begin{array}{l}\text { Snilax ovalifolia } \\
\text { (Liliaceae) }\end{array}$ & $\begin{array}{l}\text { Kukumdi- } \\
\text { ano }\end{array}$ & $\begin{array}{l}\text { Roots, fruit, } \\
\text { Tender shoots }\end{array}$ \\
\hline 28 & $\begin{array}{l}\text { Arum esculentum } \\
\text { (Araceae) }\end{array}$ & $\begin{array}{l}\text { Ban } \\
\text { karkalo }\end{array}$ & Leaves \\
\hline 29 . & $\begin{array}{l}\text { Rubia cordifolia } \\
\text { (Rubiaceae) }\end{array}$ & Majitho & Roots \\
\hline 30 & $\begin{array}{l}\text { Arisasma } \\
\text { intermedium } \\
\text { (Araceae) }\end{array}$ & $\begin{array}{l}\text { Sapa bo } \\
\text { makai }\end{array}$ & $\begin{array}{l}\text { Roots } \\
\text { Leaves }\end{array}$ \\
\hline
\end{tabular}

Ecological distribution of $P$. polyphylla and its associated species

The bio-physical data of $P$. polyphylla and its associated medicinal plants were studied by measuring frequency, relative frequency, density, relative density, relative coverage and important value index.

In the study, it was found that the frequency of $A$. intermedium was highest and G. diversifolia was lowest with values of $91 \%$ and $12 \%$, respectively (Figure 1). Frequency depends upon the occurrence of species and P. polyphylla shows frequency of only $26 \%$. It might be due to inappropriate schedule of our field work. Its proper availability time period is from April-May which was one and half month before our field work.

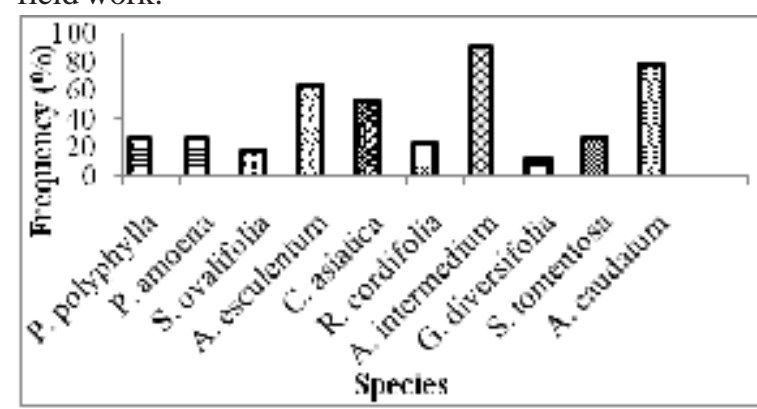

Fig. 1. Frequency of $P$. polyphylla and associated herbs

Fig. 2. indicated that $A$. intermedium has highest relative frequency of 21.68 followed by A. caudatum, A. esculentum, C. asiatica, S. tomentosa, $R$. cordifolia, P. polyphylla, P. amoena, S. ovalifolia and G. diversifolia. P. polyphylla shows an average relative frequency when compared with its associated species.
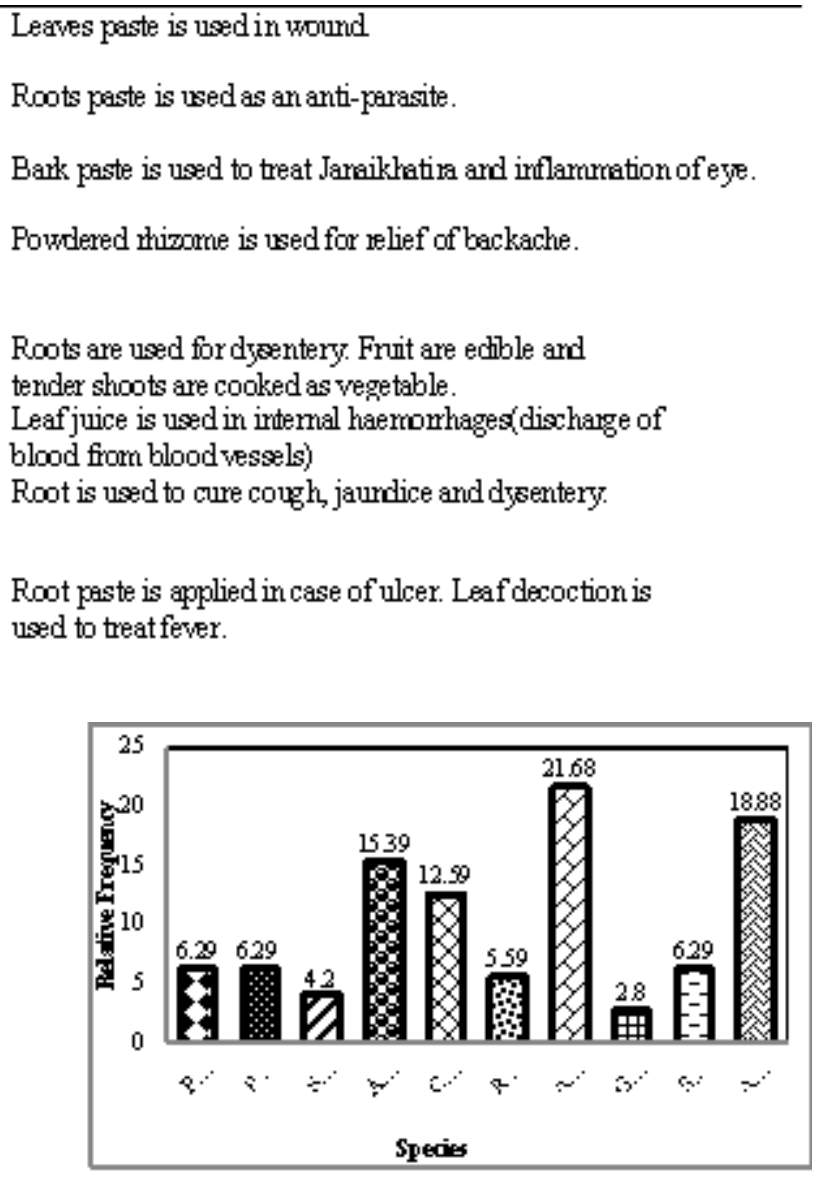

Fig. 2. Relative frequency of $P$. polyphylla and associated herbs

The study showed that A. caudatum has high density, thus is the dominant species and S. ovalifolia is a rare species among associated herbs species among which P. polyphylla has density of $1470.59 /$ ha which is below the average density (Fig. 3).

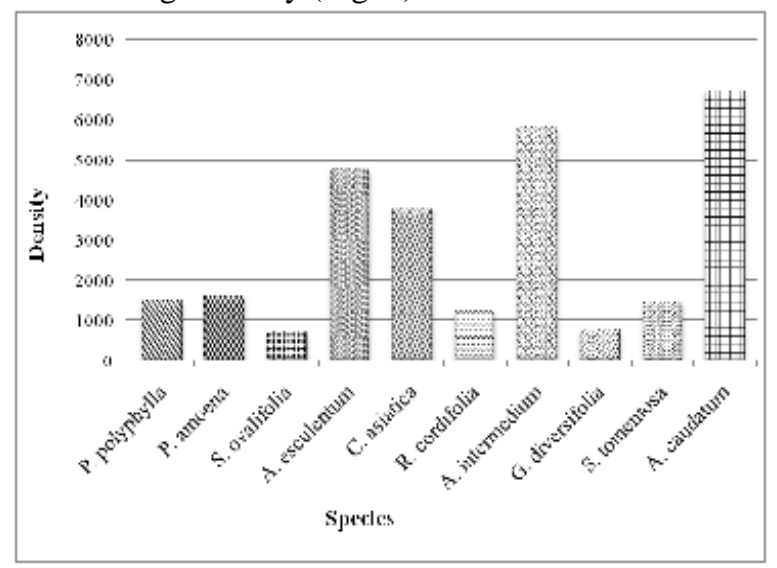

Fig. 3. Density of P. polyphylla and associated herbs 
Fig. 4 represents relative density of $P$. polyphylla and associated species. The relative density of species depends upon the occurrence of individual species. In our study, $A$. caudatum shows highest relative density due to its high availability whereas $S$. ovalifolia shows lowest relative density and $P$. polyphylla has a moderate relative density of 5.26/ha.

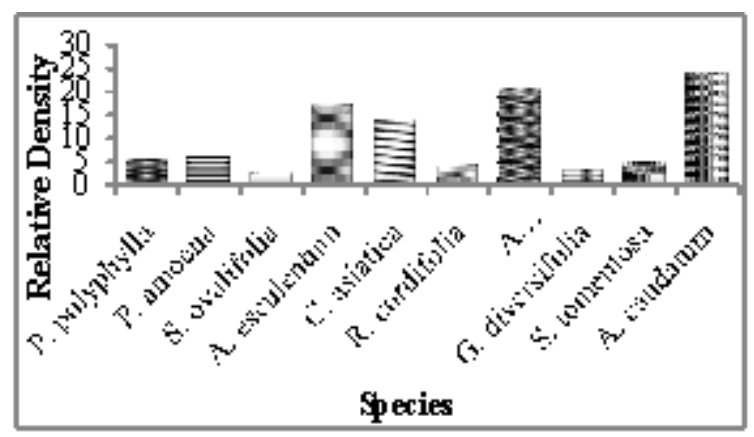

Fig. 4. Relative density of $P$. polyphylla and associated herbs and shrubs

The relative coverage pattern indicated that $A$. caudatum has highest (38.47\%) and S. ovalifolia has lowest $(1.02 \%)$ relative coverage, whereas, $P$. polyphylla shows relative coverage of $3.05 \%$ (Figure 5).

As illustrated in Figure 6, S. ovalifolia shows highest Important Value Index (IVI) of 81.30 and $A$. intermedium shows lowest value of 7.33 whereas $P$. polyphylla has IVI value of 14.6.

\section{Antibacterial activity of P. polyphylla}

The ZOI and MIC of different extracts obtained from $P$. polyphylla were determined. The ZOI of $P$. polyphylla

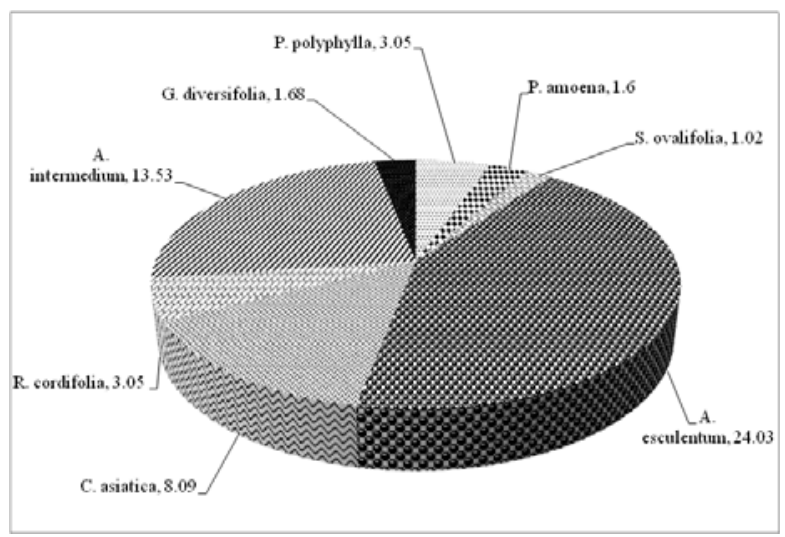

Fig. 5. Relative coverage (\%) of P. polyphylla and associated herbs and shrubs

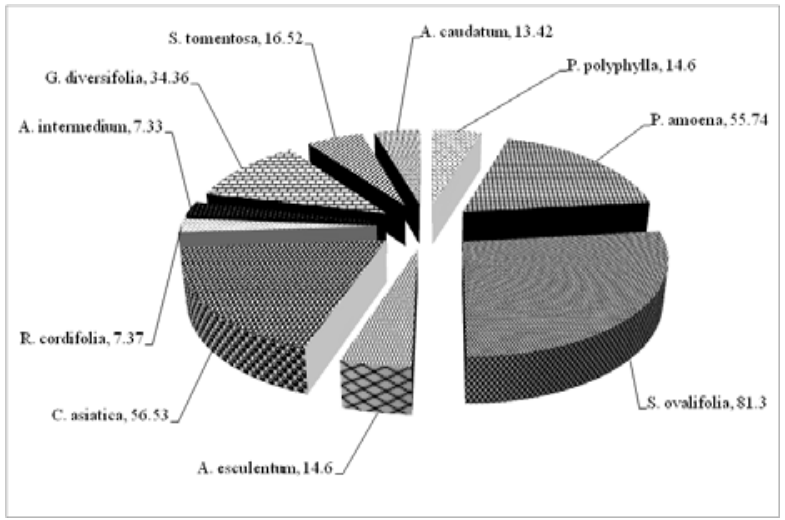

Fig. 6. Importance Value Index (IVI) of P. polyphylla and associated herbs and shrubs

The study indicated that S. ovalifolia is most important species, $P$. polyphylla the medium one and A. intermedium lowest important species.

extracts at $500 \mathrm{mg} / \mathrm{ml}$ on the tested organisms are shown in Table 2.

Table 2. ZOI of different extracts of $P$. polyphylla on tested organisms

\begin{tabular}{|c|c|c|c|c|c|c|}
\hline \multirow[t]{2}{*}{ S.N. } & \multirow{2}{*}{$\begin{array}{l}\text { Extracts and } \\
\text { standards }\end{array}$} & \multicolumn{5}{|c|}{ ZOI (rum) } \\
\hline & & S.aureus & P. aoruginosa & E.coli & S.flexineras & B. subtilis \\
\hline$\overline{1}$ & $\mathrm{P}$ & 15 & 7 & 8 & 8 & NA \\
\hline 2 & $\mathrm{C}$ & 14 & NA & NA & NA & NA \\
\hline 3 & M & 7 & NA & NA & NA & NA \\
\hline 4 & W & NA & 7 & NA & NA & $\mathrm{NA}$ \\
\hline 5 & P1 & 18 & NA & 14 & 8 & 15 \\
\hline 6 & $\mathrm{Cl}$ & 10 & 10 & 11 & 10 & 10 \\
\hline 7 & $\mathrm{Ml}$ & 9 & 7 & NA & 9 & 7 \\
\hline 8 & W1 & 7 & NA & NA & 11 & 9 \\
\hline 9 & $\mathrm{Cp}$ & 8 & 24 & 15 & 14 & 10 \\
\hline 10 & $\mathrm{Nx}$ & 11 & 26 & NA & 32 & 24 \\
\hline
\end{tabular}

Note: P, C, M and W are petrol ether, chloroform, methanol and water extracts of rhizomes of P. polyphylla. P1, C1, M1 and W1 are petrol ether, chloroform, methanol and water extracts of aerial parts of P. polyphylla. Cp and Nf are Ciprofloxacin and Norfloxacin standard antibiotics respectively, used in the assay. NA $=$ Not active. Diameter of well $=4 \mathrm{~mm}$. ZOI e- $12 \mathrm{~mm}$ was considered most active; 9-11 mm average; and from 7 to $8 \mathrm{~mm}$ less active (Cheesbrough, 1993). 
Table 2 showed that different extracts of aerial part of $P$. polyphylla were active against $B$. subtilis, $S$. aureus, $P$. aureginosa, E. coli and S. flexinerai whereas, only petrolium ether and chloroform extracts of rhizome part is active against $S$. aureus but other extracts were found to be inactive.

The ZOI of both aerial and underground parts of $P$. polyphylla in petrol ether extract was high against $S$. aureus. Therefore dilutions of 250, 125, 62.5, 31.25 and $15.62 \mathrm{mg} / \mathrm{ml}$ were prepared following the serial dilution techniques to find out its MIC which was found to be $62.5 \mathrm{mg} / \mathrm{ml}$, being the least concentration to inhibit the growth of $S$. aureus.

The study indicated that $P$. polyphylla was an important medicinal plant species having a number of ethnomedicinal, social and economical importance. This species can also be used to treat different bacterial infections for which detail investigation is needed. The distribution pattern, accessibility and perception of people towards this species and its antibacterial properties indicated that this species should be further studied to enhance the livelihood of rural communities of Nepal. Panchase forest can be a model forest for the study of P. polyphylla together with other valuable medicinal plant species from government sector and other research institutions.

\section{Acknowledgements}

We would like to acknowledge the Community Based Natural Forest and Tree Management in the Himalayas (ComForM) project for being instrumental to provide a financial support for this study. We would also like to thank local people of Bhadaure Tamagi VDC and to Khagendra Raj Baral for their kind cooperation during our research period. A part of the laboratory work has been done in Medicinal and Aromatic Plants Research Laboratory at the Institute of Forestry, Pokhara which is established with the funding support of Alexander von Humboldt Foundation, Germany.

\section{References}

Bhattarai, R.K. and D.M. Ghimere. 2006. Cultivation and sustainable harvesting of commercially important medicinal and aromatic plants of Nepal. Sampada Anyuasan Tatha Bikas Manch, Kathmandu, Nepal. 393 pp.

Cheesbrough, M. 1993. Medicinal laboratory manual for tropical countries. Environmental and Land-Based Science (ELBS) Reprinted Edition 5: 143-150.

Devkota, K.P., R. Acharya, M.P. Baral and R.P. Pokherel. 2000. Antimicrobial activity of some herbal plants used in traditional medicine in Nepal. In: Proceedings of Third National Conference on Science \& Technology (2000). Nepal Academy of Science and Technology (NAST), pp. 1311-1317.

Devkota, K.P. and I.C. Dutta. 2001. Antibacterial activities of commercially traded herbs used in traditional medicines in communities of Doti district, Nepal. Report submitted to International Union for Conservation of Nature (IUCN), Kathmandu, Nepal. $83 \mathrm{pp}$.

Dingle, J., W.W. Reed and G.I. Solomons. 1953. The enzymatic degradation of pectin and other polysaccharide. II - Application of the 'Cup-plate' assay to the estimation of enzymes. Journal of Science of Food and Agriculture 4: 149-153.

Dutta, I.C. 2007. Non timber forest products of Nepal. Hillside Press, Kathmandu, Nepal. 484 pp.

Manandhar, N.P. 1993. Ethnomedicinal note on folk-lore remedies of Baglung district, Nepal. Contributions to Nepalese Studies (CNAS) Journal 20:184-194.

Pepeljnjak, S., G. Stanik and P. Potochi. 1999. Antimicrobial activity of the ethanolic extract of Saturej montana ssp. Montana. Acta Pharmaceutical 49: 65-69.

Prajapati, N.D. and S.S. Purohit. 2003. Agro's colour atlas of medicinal plants. Agrobios, India. 268 pp.

Ravindranath, S. and S. Premnath. 1997. Biomass studies field method for monitoring biomass. Oxford and IBH publishing co. Pvt. Ltd. India. 615 pp.

Salie F., P.F.K. Eagles and H.M.J. Leng. 1996. Preliminary antimicrobial screening of four South African Asteraceae species. Journal of Ethanopharmacology 52: 27-33.

WHO. 1991. Basic laboratory procedure in clinical bacteriology. World Health Organization, Geneva. 128 pp. 
Nepal Journal of Science and Technology Vol. 13, No. 2 (2012) 167-174 